\title{
INDONESIAN CAPITAL MARKET INVESTORS' REACTION TO THE EVENTS OF THE COVID-19 PANDEMIC
}

\author{
Ani Sumarmi \\ Universitas Gajayana Malang, Malang, Indonesia \\ ani.s2201@gmail.com \\ Dyah Sawitri \\ Universitas Gajayana Malang, Malang, Indonesia \\ Umi Muawanah \\ Universitas Gajayana Malang, Malang, Indonesia \\ umimuawanah@unigamalang.ac.id \\ Abdul Halim \\ Universitas Gajayana Malang, Malang, Indonesia
}

\begin{abstract}
This study aims to analyze which sectors are affected by the announcement of the first Covid-19 patient and the announcement of the new normal in terms of abnormal returns, trading volume activity, market capitalization, and net foreign sell. The samples used were stocks included in the Kompas 100 index. Data were analyzed using an event study non-parametric statistical approach to Corrado rank test, Wilcoxon Sign-Rank test, and statistically parametric paired sample t-test using Microsoft Excel and SPSS version 26 applications. The results of the study show that the announcement of the first Covid-19 patient did not have a significant impact on the average abnormal stock return in all business sectors. However, on the fifth day after the event, there was a significant negative abnormal return in all sectors other than the technology sector. The cyclical consumer sector and the non-cyclical consumer sector were the most affected with a negative average abnormal return. The non-cyclical consumer sector also experienced an increase in net foreign sell. Furthermore, these two sectors experienced a good recovery at the time of the announcement of the implementation of the new normal policy in terms of increasing the average transaction volume in the cyclical consumer sector, and in terms of increasing market capitalization in the noncyclical consumer sector. The technology sector was the only sector that was not significantly affected on the fifth day after the announcement of the first Covid-19 patient.
\end{abstract}

Keywords: event study, abnormal return, trading volume activity, market capitalization, net foreign sell. DOI: https://doi.org/10.24818/beman/2021.S.I.2-11

\section{INTRODUCTION}

The capital market as an economic instrument cannot be separated from the influence of the economic and non-economic environment. Stock prices are mainly influenced by factors that shape the characteristics of businesses and markets (He et al., 2020). According to Altin (2015), the influence of the economic environment consists of the influence of the macro and microeconomic environment. While 
non-economic influences, although not directly related to the dynamics that occur in the capital market, cannot be separated from activities in the capital market (Diniar and Kiryanto, 2015).

One of the events that affect economic growth and capital market activities is the spread of disease outbreaks. The current disease outbreak in the world is the Covid-19 outbreak. On December 31, 2019, WHO has identified the first case of Covid-19 in Wuhan, China. In early and mid-January 2020, the virus began to spread in other provinces in China because it was driven by massive community homecoming activities during Chinese New Year celebrations. Next on January 30, 2020, WHO declared a global emergency due to the rapid spread of this virus.

The Indonesian government has taken a policy to prevent the entry of the epidemic into Indonesia by focusing on the inflow and outflow of people from China. However, it turned out that on March 2, 2020, President Joko Widodo announced that Indonesia had experienced the first case of Covid-19 that afflicted residents of Depok, West Java (Ihsanuddin, 2020). Transmission is traced to occur from Japanese citizens. Since then, the positive cases of Covid-19 in Indonesia have continued to increase.

The Indonesian government has taken a policy to prevent the entry of the epidemic into Indonesia by focusing on the inflow and outflow of people from China. However, it turned out that on March 2, 2020, President Joko Widodo announced that Indonesia had experienced the first case of Covid-19 that afflicted residents of Depok, West Java. Transmission is traced to occur from Japanese citizens. Since then, the positive cases of Covid-19 in Indonesia have continued to increase.

Stock markets in Asia reacted more quickly to the spread of the epidemic than stock markets in other continents (Liu et al, 2020), Indonesia is no exception. On March 2, 2020, the JCl (Jakarta Composite Index) closed at 5,361.25, down 91.45 points compared to the closing of the previous working day. This weakening continues to occur in line with the occurrence of various other events related to Covid-19, including the death of the first patient, and the president's call for social distancing measures. $\mathrm{JCl}$ finally reached its lowest point on March 24, 2020, at 3,937.63. Next the index underwent a positive adjustment towards the new equilibrium price at around 4,500.

Over time, the government realized that the pressure on the economy could not be allowed to continue. On the one hand, the government cannot continue to subsidize the affected communities, but on the other hand, the government is responsible for suppressing and even eliminating the spread of the epidemic. Along with the implementation of the Large-Scale Social Restriction policy in several cities, then on Friday, May 15,2020 , the government stated the necessity to make adjustments to the pandemic situation, namely by enacting the New Normal policy to help the movement of the economy while controlling the spread of the epidemic.

News about the implementation of the New Normal has a positive impact on the next trading week. On Monday 18 May 2020, the JCl slightly strengthened by 3.45 points to 4,511.06, and on 19 May 2020, the 
$\mathrm{JCl}$ strengthened by 37.60 points to $4,548.66$. Although it had slightly decreased on May 20, 2020, along with the issuance of regulations regarding the New Normal, namely the Decree of the Minister of Health Number HK.01.07/MENKES/328/2020 concerning Guidelines for the Prevention and Control of Covid-19 in Office and Industrial Workplaces in Supporting Business Continuity in Situations Pandemic, but then the upward trend in the $\mathrm{JCl}$ continues to this day. Based on two phenomena, namely the announcement of the presence of Covid-19 patients in Indonesia and the announcement of the implementation of the New Normal, it can be assumed that this information affects stock prices.

The stock market capitalization value during the Covid-19 pandemic can also be observed to show the wealth value of investors who invest their funds in the capital market. Investors of course always expect the value of their wealth to continue to increase so that a decline in market capitalization is avoided as much as possible. Based on data from the Indonesia Stock Exchange (IDX) at the end of 2019, the market capitalization of the $\mathrm{JCl}$ amounted to more than Rp. 7,265 trillion, while on March 13, 2020, the market capitalization of the $\mathrm{JCl}$ fell drastically to Rp. 5,678.25 trillion. This means that within three months, the market capitalization of the $\mathrm{JCl}$ fell by $21.84 \%$ (Pransuamitra, 2020). The decline in the market capitalization of the $\mathrm{JCl}$ can also be observed in different business sectors.

Furthermore, the state of the stock market in the midst of the Covid-19 pandemic can also be observed from the composition of capital ownership. The report stated that there was a capital outflow in the form of Government Securities (SBN) amounting to Rp. 153.4 trillion and shares of Rp. 13.4 trillion (Fitriani, 2020). The occurrence of capital outflows in the stock market can be observed from the number of net foreign sells that occur in each different business sector.

To examine the phenomena of stock market movements, it is necessary to conduct further research on the state of the stock market around the announcement of the first Covid-19 patient and the announcement of the New Normal policy. In addition, the stock price fluctuations that occur should not only be seen in terms of weakening and strengthening stock prices but can also be used as an evaluation of how the state of economic stability in Indonesia is. The reaction of Indonesian capital market investors in this study is proxied by changes in abnormal returns, trading volume activity, market capitalization, and net foreign sell. Furthermore, this study also aims to find out how the impact of the incident on each different business sector.

\section{LITERATURE REVIEW}

The theory of market reactions to events originally appeared in Dolley's (1933) research. This study uses a sample of 5 companies that do stock splits. This study finds evidence that most stock prices react positively because of this stock split event. 
After the research of Dolley (1933), Ball and Brown (1968), Beaver (1968), and Fama et al. (1969) conducted a study using event studies. Ball and Brown use returns and abnormal returns as proxies to determine the market reaction. This study finds evidence that there is an effect of information on changes in earnings and cash flow on abnormal returns. Next Beaver examines the effect of information content on trading volume and stock price movements. He found that trading volume activity and return volatility increased at the time of earnings announcements. Meanwhile, Fama conducted research on the occurrence of stock split announcements and found that the stock market adjusts very quickly when there is information about a stock split.

From their impact, events can be grouped as having a specific impact on certain companies only, the impact on all companies in an industry, and a general impact on all companies in the capital market (Hartono, 2018). The research of Liu et al (2020) shows that an event can be measured its impact on various industrial sectors. It turns out that various industrial sectors can show different reactions to the same event.

Research on the information content of the occurrence of an event has been widely carried out. Most of the research conducted revolves around political events. Research by Ghanem and Rosvall (2014), Hatmanti and Bambang (2017), Mahmood et al., (2014), Najaf et al., Sasongko et al., (2015), Yuliana and Sudana (2015) found that there was an abnormal return that significant in the period following a particular political event. While different results were found in the research of Hung (2013), Octafilia (2016), Murekachiro (2014), Yuniarthi and Sujana (2016), and Wong and Hooy (2016) which found that there was no significant abnormal return in the period after the political events studied.

Research on the information content of the occurrence of an event, especially in disease outbreaks, has been carried out including by Liu et al., (2020). Liu found that countries in Asia experienced negative abnormal returns with a greater value when compared to other countries during the Covid-19 pandemic. Marin"c (2016) found that during the Ebola pandemic, the effect of declining stock values in America will be increasingly felt in small company stocks, volatile stocks, and stocks in unstable industries. Chen, Shawn, and Gon (2007) found (that the share of hotels in Taiwan experienced a decline during the SARS outbreak. Hotel stocks in Taiwan also experienced a negative and significant average cumulative abnormal return during and after the day the outbreak was discovered in that country. While He, Sun, Zhang, and Li (2020) found that in the China Stock Market, the transportation, mining, electricity and heating sectors, as well as the environmental industry suffered losses due to the pandemic. As for the manufacturing sector, information technology, education, and the health industry can survive in the midst of a pandemic.

The stock market capitalization value and composition of capital ownership can be observed to change during the Covid-19 pandemic. There was a decrease in market capitalization of the $\mathrm{JCl}$ by $21.84 \%$ in the 
first 3 months of 2021. The news also stated that there was a capital outflow in the form of Government Securities (SBN) of Rp. 153.4 trillion and shares of Rp. 13.4 trillion. The occurrence of capital outflows in the stock market can be observed from the number of net foreign sells.

Therefore, the hypothesis in this study is as follows:

$\mathrm{H} 1$ : There is an average abnormal return in the announcement of the first Covid-19 patient on stocks with different business sectors.

$\mathrm{H} 2$ : There is an average abnormal return in the announcement that the new normal will apply to stocks with different business sectors.

$\mathrm{H} 3$ : There is a difference in the average trading volume activity in the announcement of the first Covid-19 patient in stocks with different business sectors.

$\mathrm{H} 4$ : There is a difference in the average trading volume activity in the announcement that the new normal will apply to stocks with different business sectors.

H5: There is a difference in the average market capitalization in the announcement of the first Covid-19 patient in stocks with different business sectors.

H6: There is a difference in the average market capitalization in the announcement that the new normal will apply to stocks with different business sectors.

$\mathrm{H7}$ : There is a difference in the average net foreign sell in the announcement of the first Covid-19 patient in stocks with different business sectors.

H8: There is a difference in the average net foreign sell in the announcement that the new normal will apply to stocks with different business sectors.

The following is a picture of the framework of this research. 


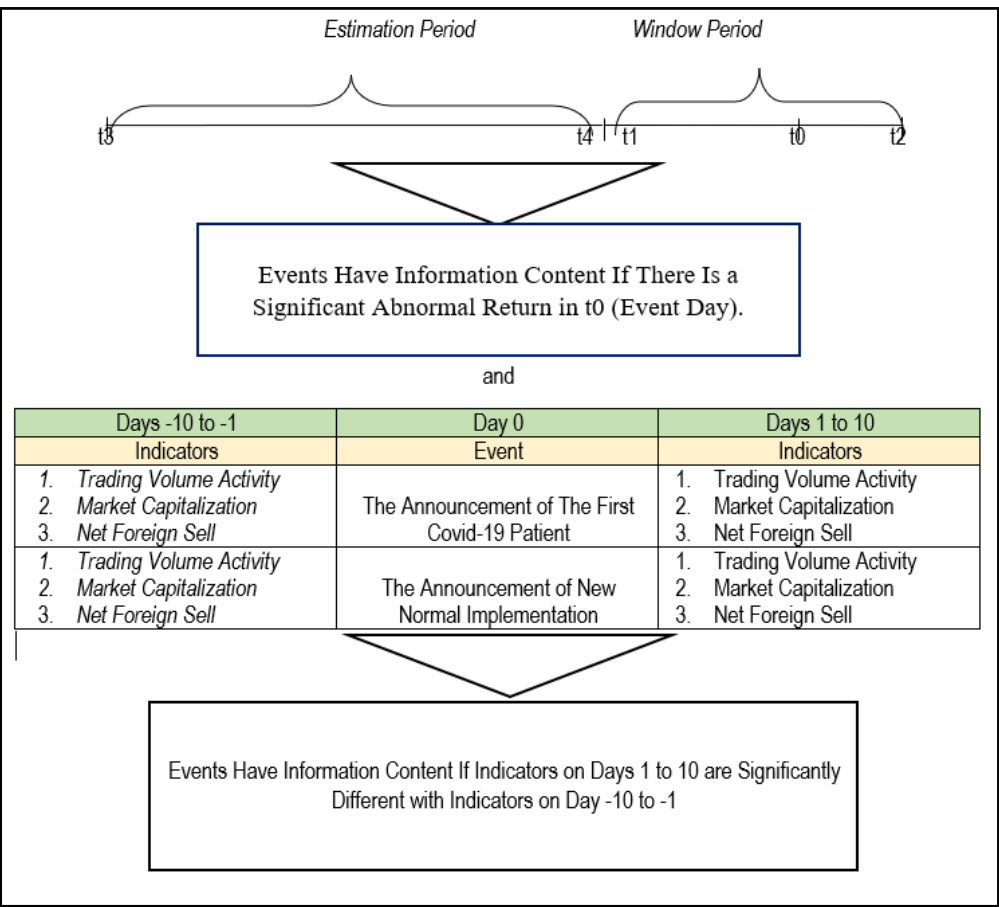

FIGURE 1. RESEARCH FRAMEWORK

Source: Developed by Researchers

\section{RESEARCH METHODE}

This research was conducted on the Indonesia Stock Exchange. The research time was chosen ten days before, the day of the announcement, and ten days after the announcement of the first Covid-19 patient and the announcement that the new normal would be enforced. The sample of this study is the shares of companies' members of the Kompas 100 Index. The procedure used to determine the research sample is the purposive sampling method, which is a sampling technique carried out with certain considerations. The reason the researchers chose the Kompas 100 Index sample is because this research analyzes daily changes that require liquid stocks so that the effect of an event can be measured immediately and accurately. The Kompas 100 Index stocks are the types of stocks that are widely traded on the exchange, so they can reflect the interest of the public in general. In addition, the Kompas 100 Index is a stock index based on a liquidity category with the most members among other liquid stock index.

The data comes from the Indonesia Stock Exchange website. Analysis of abnormal returns using the event study method, and analysis of trading volume activity, market capitalization and net foreign sell using parametric and non-parametric statistical methods paired sample t-test or Wilcoxon sign rank test. 


\subsection{Variables and Measurements}

Average Abnormal Return is the average excess of the actual return on stocks in a particular sector to the expected return. Abnormal return is the difference between the actual return and the expected return. Actual return is calculated using the formula according to the book from Hartono (2018).

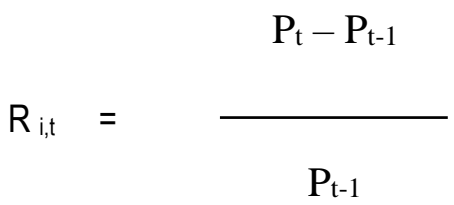

Where :

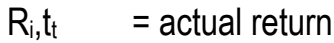

$\mathrm{P}_{\mathrm{t}} \quad=$ current security price.

$\mathrm{P}_{\mathrm{t}-1} \quad=$ the price of the security period one day ago.

Expected return is calculated using the mean adjusted model. The mean adjusted model assumes that the expected return is constant which is the same as the previous average realized return during the estimation period. Expected return is calculated using the formula according to the book from Hartono (2018).

$$
E\left(R_{i t}\right)=\frac{\sum_{j=t 3}^{t 4} R i, j}{T}
$$

\section{Where}

$E\left(R_{i, t}\right)=$ expected return of the $i-$ th company in the t event period

$\mathrm{Ri}_{\mathrm{i}, \mathrm{j}} \quad=$ realized return of the $\mathrm{i}$-th company in the jth estimation period.

$\mathrm{T}=$ = the length of the estimation period, which is from $\mathrm{t} 3$ to $\mathrm{t} 4$ as shown on exhibit on Figure 1.

Trading volume activity is the total number of shares traded on the stock exchange for a certain period. This model can be formulated as follows according to Foster's (1986) book.

$$
\mathrm{TVA}_{\mathrm{i}, \mathrm{t}}=\frac{\sum \mathrm{T}_{\mathrm{i}, \mathrm{t}}}{\sum \mathrm{V}_{\mathrm{i}, \mathrm{t}}}
$$

Where :

TVA $_{i, t}=$ trading volume activity for the i-th security on the t-th day. 
$\mathrm{T}_{\mathrm{i}, \mathrm{t}} \quad=$ shares of company $\mathrm{i}$ traded at time $\mathrm{t}$.

$\mathrm{V}_{\mathrm{i}, \mathrm{t}} \quad=$ shares of company $\mathrm{i}$ outstanding at time $\mathrm{t}$.

After each TVA is known, then the average trading volume activity of shares according to Foster (1986) is calculated using the following method:

$$
\operatorname{ATVA}_{\mathrm{t}}=\frac{\sum_{i=1}^{n} T V A i, t}{n}
$$

Where :

ATVA $_{t}=$ average trading volume activity on day $t$.

$\mathrm{TVA}_{i, t} \quad=$ trading volume activity for the $\mathrm{i}$-th security on the t-th day.

$\mathrm{n} \quad=$ number of securities.

Market capitalization or market capitalization is the prevailing price of securities (Downes and Goodman, 2003). Market capitalization reflects the value of the company's current wealth which is a measurement of the size of the company. To calculate market capitalization, multiply the number of shares with the share price of each Kompas-100 member company every day before and after the event.

Net foreign sell is the value of net sale of shares made by foreign investors (overseas investors) at a certain time. The daily net foreign sell data can be obtained on the Indonesia Stock Exchange website.

\subsection{Data Analysis}

Data analysis was performed using Microsoft Excel and SPSS version 26 software. In the hypothesis tests 1 and 2, the analysis of the average abnormal return data can be carried out using parametric and non-parametric tests., depending on the results of the data normality test. Dombrow, Rodriguez, and Sirman (2000) show that the lack of abnormal return data which is normally distributed causes a large number of nonparametric tests. Corrado (1989) proposed a rank test.

How to use the rank test test can be explained as follows. For example, there are $\mathrm{N}$ securities in the event study and L2 abnormal returns for each security, the test is carried out by sorting the abnormal returns for each security. The value of this sequence for example is Kit. The ranking test uses the fact that the expected rank of an event date is $(L 2+1) / 2$ for a null hypothesis test. Statistical testing by determining the statistical $Z$ value for this null hypothesis is as follows as shown in Hartono (2018). 
$s(K)=\sqrt{\frac{1}{L_{2}} \sum_{t=t_{3}}^{t_{2}}\left(\frac{1}{N} \sum_{i=1}^{N}\left(K_{i t}-\frac{L 2+1}{2}\right)\right)^{2}}$

and

$$
Z=\frac{\frac{1}{N} \sum_{i=1}^{N}\left(K_{i t}-\frac{L_{2}+1}{2}\right.}{s(K)}
$$

\section{Where :}

$\mathrm{S}(\mathrm{K})=$ Standard deviation of the order of values.

Kit $=$ the value of the order (rank) of the I-th securities abnormal return on the t-th date.

$\mathrm{L} 2$ = number of sample periods

$\mathrm{N}=$ number of companies

Furthermore, a comparison is made between $Z$ count and $Z$ table by first determining the significance level of $5 \%(a=5 \%)$. If $Z$ count $Z$ table then the hypothesis can be accepted.

A normality test is used to determine whether data is normally distributed or not. The normality test will determine the statistical test tool to be used in testing the hypothesis. The normality test of the data was carried out using the Kolmogorov-Smirnov test. The normality test criteria is if the probability value $>$ level of significant $(\alpha=5 \%)$ then the data is declared normally distributed, otherwise if the probability value is < level of significant $(\alpha=5 \%)$ then the data is declared to be not normally distributed.

From the results of normality, it can be determined testing techniques for hypotheses 1 and 2 . If the results of the data are normally distributed, then the hypothesis testing technique uses the T-Test test, but if the data is not normally distributed, the test is carried out using the Corrado Rank-Test.

In hypothesis testing 3 to 8 which is an analysis of trading volume activity, market capitalization, and net foreign sell data, normality tests are carried out on trading volume activity, market capitalization, and net foreign sell data on ten days before and ten days after the event, namely ( $t=-10$ to $t=-1)$ and ( $t=1$ to $t=10)$. If the results of the data are normally distributed, then the technique for testing hypothesis 3 to 8 is carried out using a paired sample t-test parametric statistic test. Meanwhile, if the data is not normally distributed, then the technique for testing hypothesis 3 to 8 is carried out a non-parametric Wilcoxon Sign-Rank Test statistic test.

\section{RESULT AND DISCUSSION}

The number of issuer companies listed on the Indonesia Stock Exchange as of April 2, 2021, is 731. To provide information and a more complete picture of the development of the stock exchange to the public, 
the IDX disseminates data on stock price movements through print and electronic media. One indicator of stock price movements is the stock price index.

The Kompas 100 Index is a stock index of 100 shares of public companies traded on the Indonesia Stock Exchange. The Kompas 100 index was officially published by the Indonesia Stock Exchange (IDX) in collaboration with the Kompas newspaper on Friday, August 10, 2007. The selected stocks to be included in the Kompas 100 index, apart from having high liquidity and large market capitalization, are also stocks that have good fundamentals and performance. Because the capital market in Indonesia has the characteristics of a thin market, namely a market with some passively traded securities, the use of the Compass 100 Index in this study is considered to represent the behavior of Indonesian Stock Exchange investors in general.

Starting January 25, 2020, the IDX implemented a new classification of listed companies' sectors and industries called the "Indonesia Stock Exchange Industrial Classification" or IDX-IC replacing the "Jakarta Stock Industrial Classification" or (JASICA) which was used since 1996. This recorded includes 12 sectors replacing the old 9 sectors. These twelve sectors are the energy sector, basic materials, industrials, consumer cyclicals, consumer non-cyclicals, healthcare, financials, properties \& real estate, technology, infrastructures, transportation and logistics, and listed investment products.

The following figure 2 shows the composition of the company sectors that are included in the Kompas 100 Index.

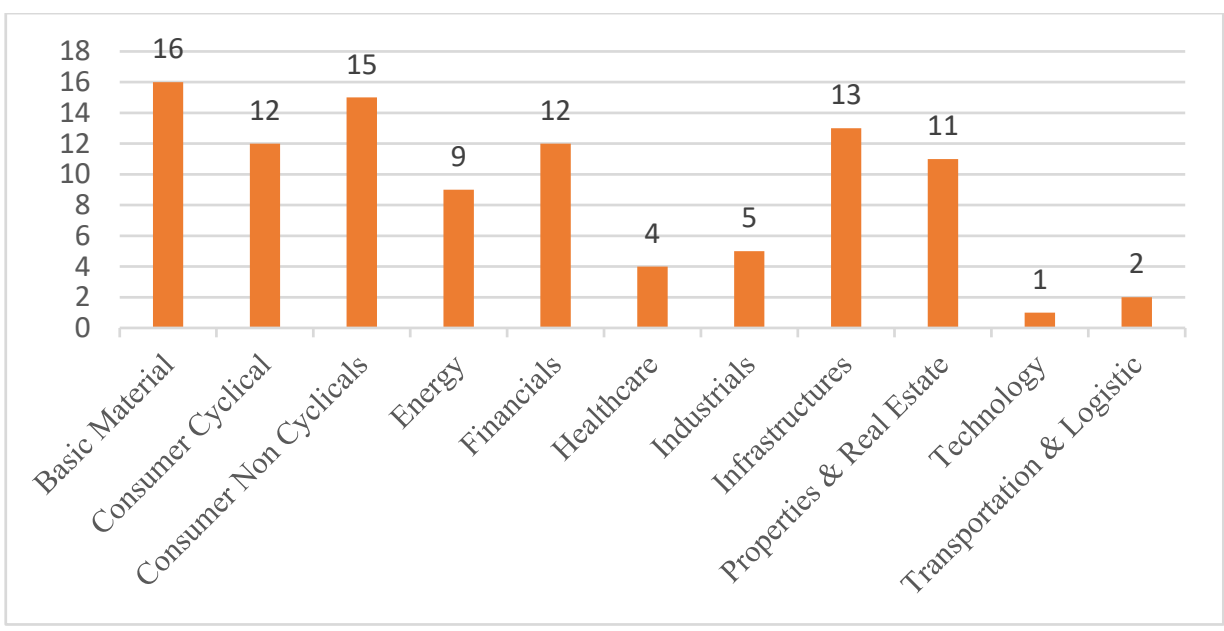

FIGURE 2. NUMBER OF COMPANIES FROM VARIOUS SECTORS

Source: IDX Website, Processed by Researchers.

In Figure 2, it can be seen that the companies that are included in the basic materials sector have the most number, namely 16 members, while those that are included in the technology sector there is only one member. No shares are included in the Listed Investment Products because the Listed Investment 
Products Sector only includes investment products listed on the Indonesia Stock Exchange such as trusts, mutual funds, and bonds.

Furthermore, abnormal return data on the announcement of Covid-19 patients can be observed in figure 3. In the estimation period, it can be observed that there is a fairly fluctuating average abnormal return between the occurrence of a positive average return and a negative average return. The transportation and logistics sector saw large fluctuations in the -32 and -31 days before the announcement of the first Covid-19 patient.

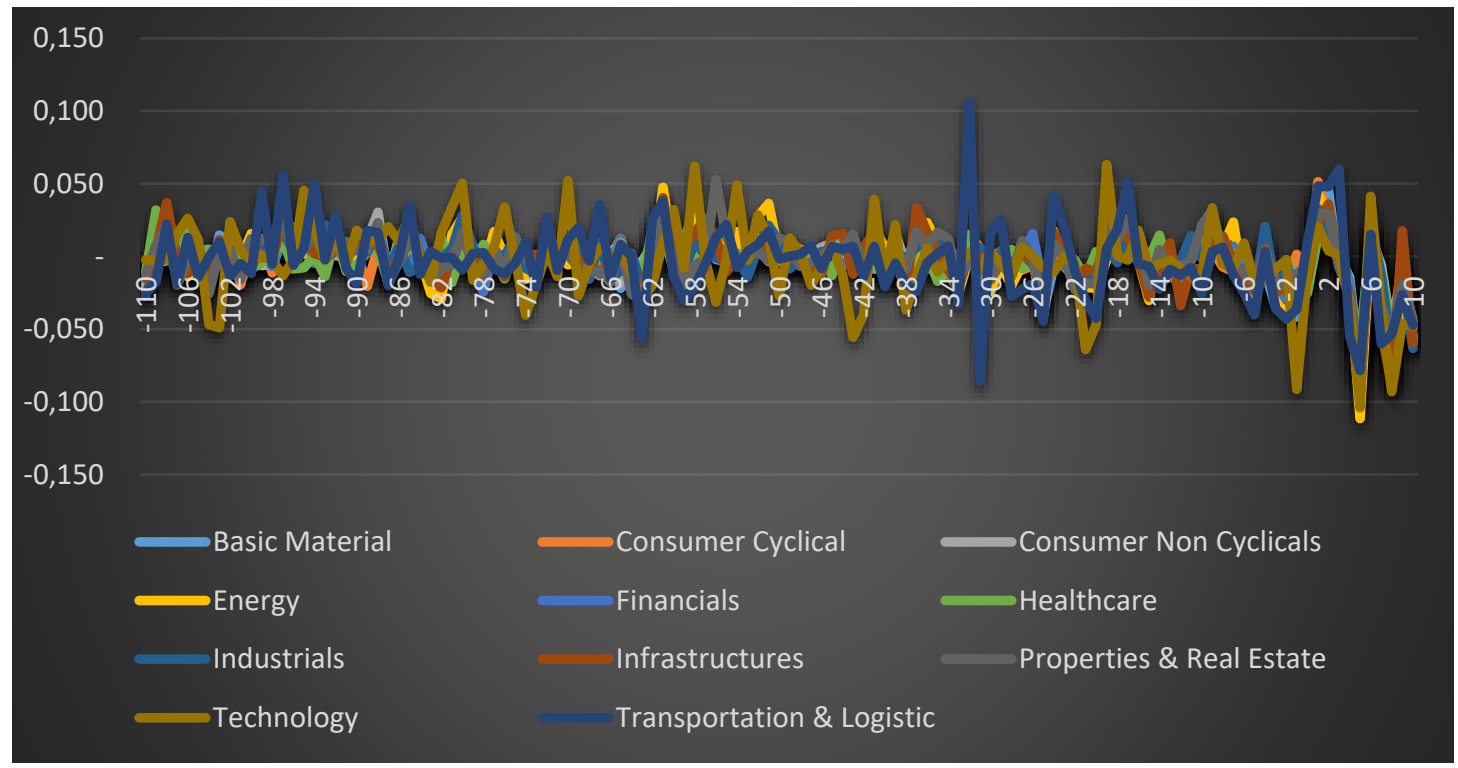

\section{FIGURE 3. AVERAGE ABNORMAL RETURN IN THE ESTIMATION PERIOD AND WINDOW PERIOD OF THE ANNOUNCEMENT OF THE FIRST COVID-19 PATIENT}

Source: IDX Website, Processed by Researchers.

Throughout the event window period for the announcement of the first Covid-19 patient, it can be observed that all industrial sectors have a synchronized average movement of abnormal returns. It is only seen that the technology business sector has significant volatility on the day before the event. The transportation and logistics sector seems to still experience an increase in abnormal returns on the third day after the incident, whereas for other companies, abnormal returns have decreased. Furthermore, it can also be seen that all sectors experienced the lowest negative abnormal return on the fifth day, with the energy sector experiencing the lowest decline.

Furthermore, abnormal return data on the announcement of the implementation of the new normal can be observed in figure 4 as follows. 


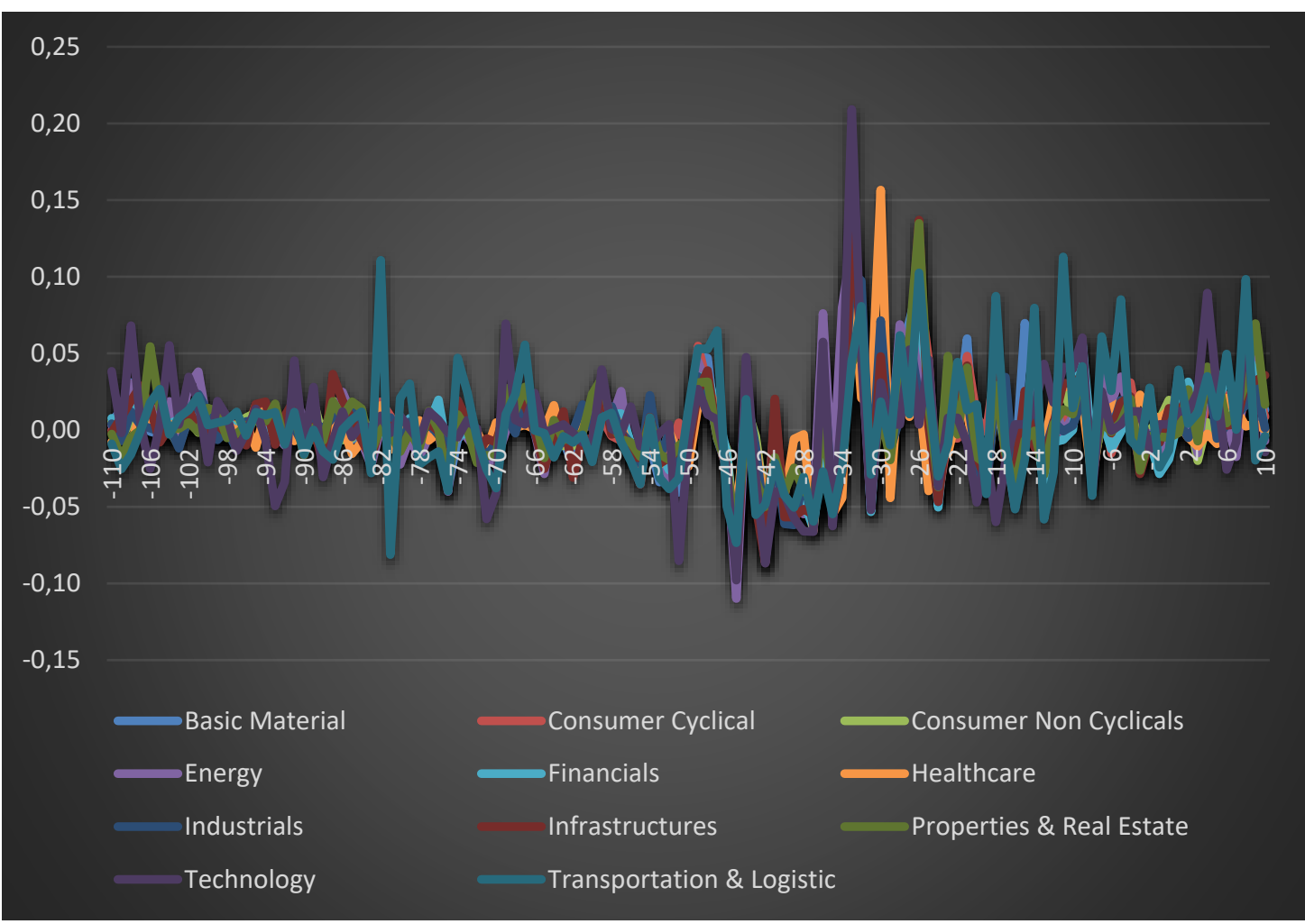

FIGURE 4. AVERAGE OF ABNORMAL RETURN IN THE ESTIMATION PERIOD AND THE WINDOW PERIOD OF THE EVENT ANNOUNCEMENT WILL IMPLEMENT THE NEW NORMAL

Source: IDX Website, Processed by Researchers.

Based on figure 4, in the estimation period, it can be observed that there is an average abnormal return that increases in fluctuation starting from the 50th day before the event. The technology and healthcare sectors experienced more positive abnormal returns around day 35 to day 29 before the event. Meanwhile, other sectors also experienced sharper fluctuations starting on the 35th day before the event compared to the previous day. The 35th day before the event was March 23, 2020. On that date, the number of confirmed positive Covid-19 in Indonesia reached 579 and there was no sign of improvement in the situation. This situation can be understood as the effect of a pandemic that has begun to spread in the territory of Indonesia.

In the event period, there is an average abnormal return that differs between industrial sectors. In the graph, it can be seen that the average abnormal return tends to be less volatile than the situation around the 35 th day before the incident.

In the trading volume activity, market capitalization, and net foreign sell data, fluctuations are seen during the window period of the announcement of the first Covid-19 patient (Event I) and the announcement that the new normal will be implemented (Event II). 


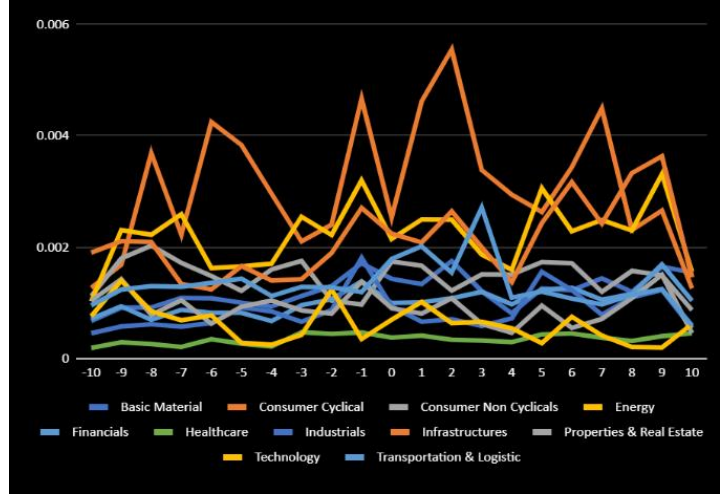

FIGURE 5. AVERAGE TRADING VOLUME ACTIVITY EVENT I

Source: IDX Website, Processed by Researchers.

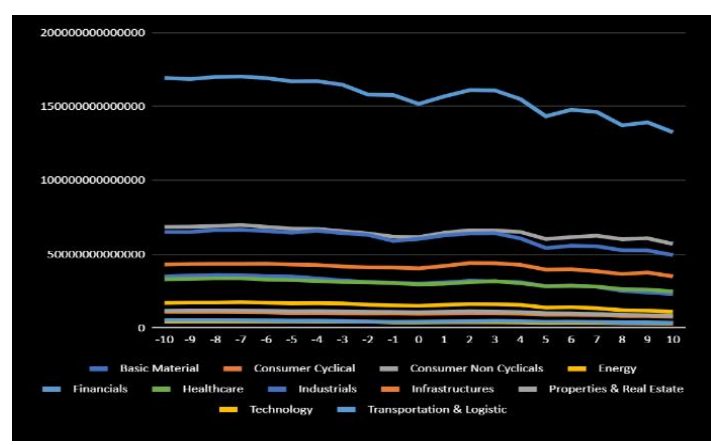

FIGURE 7 .

AVERAGE MARKET CAPITALIZATION EVENT I

Source: IDX Website, Processed by Researchers.

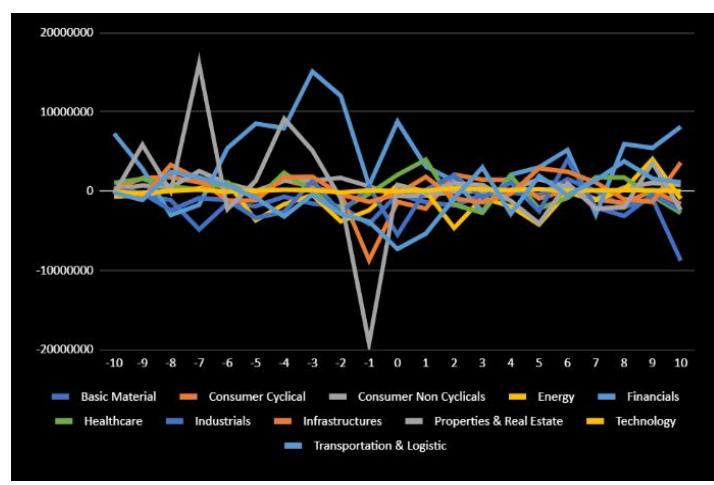

FIGURE 9. AVERAGE NET FOREIGN SELL ACTIVITY EVENT I

Source: IDX Website, Processed by Researchers.

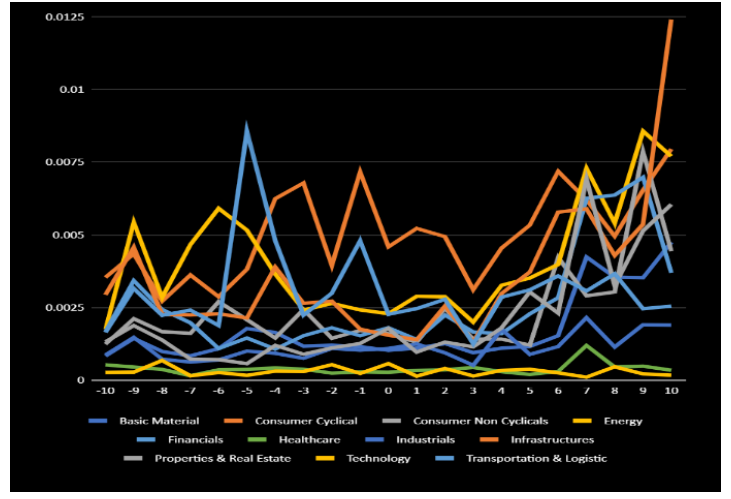

FIGURE 6. AVERAGE TRADING VOLUME ACTIVITY EVENT II

Source: IDX Website, Processed by Researchers.

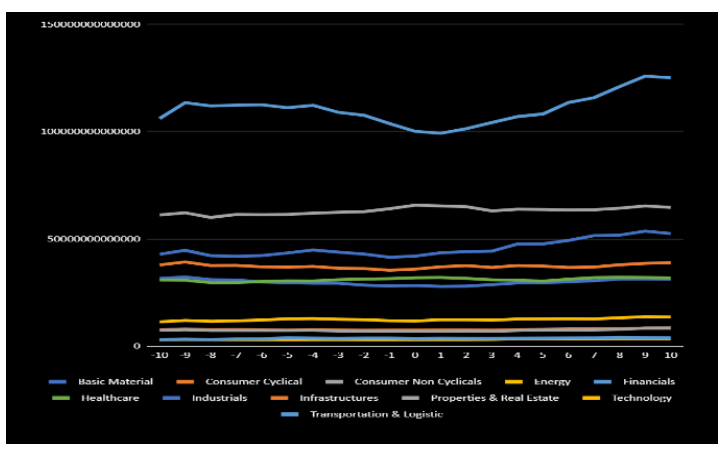

FIGURE 8.

AVERAGE MARKET CAPITALIZATION EVENT II

Source: IDX Website, Processed by Researchers.

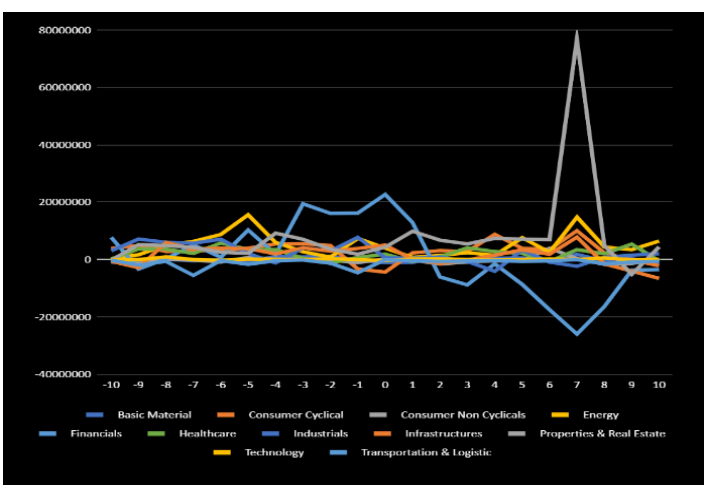

FIGURE 10. AVERAGE NET FOREIGN SELL EVENT II

Source: IDX Website, Processed by Researchers.

\subsection{Hypothesis Test}


Before testing the hypothesis, the normality test was conducted using the Kolmogorov Smirnov Test with $=5 \%$. After the normality test was carried out and the conditions for the distribution of the data were known, the suitable hypothesis testing tool was selected, namely as follows:

TABLE 1. RESULTS OF TESTING DATA NORMALITY AND SELECTION OF SUITABLE HYPOTHESES TESTING TOOLS

\begin{tabular}{|c|c|c|c|}
\hline No. & Data & Data Scatter & $\begin{array}{c}\text { Hypothesis Testing } \\
\text { Tool }\end{array}$ \\
\hline 1. & $\begin{array}{l}\text { Stock abnormal return data for each sector in the } \\
\text { estimation period of the announcement of the first } \\
\text { Covid- } 19 \text { patient. }\end{array}$ & $\begin{array}{l}\text { abnormal } \\
\text { data }\end{array}$ & Corrado Rank Test \\
\hline 2. & $\begin{array}{l}\text { Stock abnormal return data for each sector in the } \\
\text { estimation period of the announcement event will } \\
\text { apply the new normal. }\end{array}$ & $\begin{array}{l}\text { abnormal } \\
\text { data }\end{array}$ & Corrado Rank Test \\
\hline 3. & $\begin{array}{l}\text { Data on the average trading volume activity data of } \\
\text { each sector in the window period before and after the } \\
\text { announcement of the first Covid-19 patient. }\end{array}$ & $\begin{array}{l}\text { abnormal } \\
\text { data }\end{array}$ & $\begin{array}{l}\text { Wilcoxon Sign-Rank } \\
\text { Test }\end{array}$ \\
\hline 4. & $\begin{array}{l}\text { Data on the average trading volume activity of each } \\
\text { sector in the window period before and after the } \\
\text { announcement event will apply the new normal. }\end{array}$ & $\begin{array}{l}\text { abnormal } \\
\text { data }\end{array}$ & $\begin{array}{l}\text { Wilcoxon Sign-Rank } \\
\text { Test }\end{array}$ \\
\hline 5. & $\begin{array}{l}\text { The average market capitalization data for each } \\
\text { sector in the window period before and after the } \\
\text { announcement of the first Covid- } 19 \text { patient. }\end{array}$ & $\begin{array}{l}\text { abnormal } \\
\text { data }\end{array}$ & $\begin{array}{l}\text { Wilcoxon Sign-Rank } \\
\text { Test }\end{array}$ \\
\hline 6. & $\begin{array}{l}\text { Data on the average market capitalization of shares } \\
\text { for each sector in the window period before and after } \\
\text { the announcement event will apply the new normal. }\end{array}$ & normal data & $\begin{array}{l}\text { Paired Sample T- } \\
\text { Test }\end{array}$ \\
\hline 7. & $\begin{array}{l}\text { Data on the average net foreign sell shares of each } \\
\text { sector in the window period before and after the } \\
\text { announcement of the first Covid- } 19 \text { patient. }\end{array}$ & $\begin{array}{l}\text { abnormal } \\
\text { data }\end{array}$ & $\begin{array}{l}\text { Wilcoxon Sign-Rank } \\
\text { Test }\end{array}$ \\
\hline 8. & $\begin{array}{l}\text { Data on the average net foreign sell shares of each } \\
\text { sector in the window period before and after the } \\
\text { announcement event will apply the new normal. }\end{array}$ & $\begin{array}{l}\text { abnormal } \\
\text { data }\end{array}$ & $\begin{array}{l}\text { Wilcoxon Sign-Rank } \\
\text { Test }\end{array}$ \\
\hline
\end{tabular}

\section{Source: Data Processed by Researchers}

The results of the hypothesis test show as the following : 
TABLE 2. SUMMARY OF HYPOTHESIS TESTING RESULTS

\begin{tabular}{|c|c|c|c|}
\hline No & Hypothesis & $\begin{array}{l}\text { Test Tools and } \\
\text { Hypothesis } \\
\text { Testing Results }\end{array}$ & Explanation \\
\hline 1 & $\begin{array}{l}\text { There is a difference in the average } \\
\text { abnormal return in the announcement of } \\
\text { the first Covid- } 19 \text { patient on stocks with } \\
\text { different business sectors. }\end{array}$ & $\begin{array}{l}\text { Corrado Rank } \\
\text { Test } \\
\text { The hypothesis is } \\
\text { not accepted }\end{array}$ & $\begin{array}{l}\text { At the time of the event, there was } \\
\text { no significant difference in the } \\
\text { average abnormal return in various } \\
\text { business sectors. The average } \\
\text { significant abnormal return in } \\
\text { almost all sectors occurred on the } \\
\text { fifth day after the announcement of } \\
\text { the first Covid-19 patient. It turned } \\
\text { out that the cyclical consumer } \\
\text { sector experienced the most } \\
\text { significant negative abnormal } \\
\text { return on that day, followed by the } \\
\text { non-cyclical consumer sector. The } \\
\text { technology sector is the only sector } \\
\text { that is not significantly affected }\end{array}$ \\
\hline 2 & $\begin{array}{l}\text { There is a difference in the average } \\
\text { abnormal return in the announcement } \\
\text { event that the new normal will apply to } \\
\text { stocks with different business sectors. }\end{array}$ & $\begin{array}{l}\text { Corrado Rank } \\
\text { Test } \\
\text { The hypothesis is } \\
\text { not accepted }\end{array}$ & $\begin{array}{l}\text { During and after the day the event } \\
\text { occurred, there was no significant } \\
\text { difference in the average abnormal } \\
\text { return in various business sectors. } \\
\text { The cyclical consumer sector } \\
\text { experienced a significant positive } \\
\text { abnormal return on the ninth day } \\
\text { before the event. }\end{array}$ \\
\hline 3 & $\begin{array}{l}\text { There is a difference in the average } \\
\text { trading volume activity in the } \\
\text { announcement of the first Covid-19 } \\
\text { patient in stocks with different business } \\
\text { sectors. }\end{array}$ & $\begin{array}{l}\text { Wilcoxon Sign- } \\
\text { Rank Test } \\
\text { The hypothesis is } \\
\text { accepted }\end{array}$ & $\begin{array}{l}\text { Significant in the financials and } \\
\text { infrastructure sector with an } \\
\text { increasing trend. }\end{array}$ \\
\hline
\end{tabular}




\begin{tabular}{|c|c|c|c|}
\hline & $\begin{array}{l}\text { There is a difference in the average } \\
\text { trading volume activity in the } \\
\text { announcement that the new normal will } \\
\text { apply to stocks with different business } \\
\text { sectors. }\end{array}$ & $\begin{array}{l}\text { Wilcoxon Sign- } \\
\text { Rank Test } \\
\text { The hypothesis is } \\
\text { accepted }\end{array}$ & $\begin{array}{l}\text { Significant in the cyclical and non- } \\
\text { cyclical consumer sectors. The } \\
\text { cyclical consumer sector tends to } \\
\text { increase, while the non-cyclical } \\
\text { consumer sector has a downward } \\
\text { trend. }\end{array}$ \\
\hline 5 & $\begin{array}{l}\text { There is a difference in the average } \\
\text { market capitalization in the } \\
\text { announcement of the first Covid-19 } \\
\text { patient in stocks with different business } \\
\text { sectors. }\end{array}$ & $\begin{array}{l}\text { Wilcoxon Sign- } \\
\text { Rank Test } \\
\text { The hypothesis is } \\
\text { accepted }\end{array}$ & $\begin{array}{l}\text { Significantly decreased after } \\
\text { events across sectors. The } \\
\text { infrastructure sector is the least } \\
\text { affected. }\end{array}$ \\
\hline 6 & $\begin{array}{l}\text { There is a difference in the average } \\
\text { market capitalization in the } \\
\text { announcement that the new normal will } \\
\text { apply to stocks with different business } \\
\text { sectors. }\end{array}$ & $\begin{array}{l}\text { Paired Sample T- } \\
\text { Test } \\
\text { The hypothesis is } \\
\text { accepted }\end{array}$ & $\begin{array}{l}\text { Significantly increased in the non- } \\
\text { cyclical consumer sector, energy, } \\
\text { healthcare, industrials, technology, } \\
\text { and transportation and logistics. }\end{array}$ \\
\hline 7 & $\begin{array}{l}\text { There is a difference in the average net } \\
\text { foreign sell in the announcement of the } \\
\text { first Covid-19 patient in stocks with } \\
\text { different business sectors. }\end{array}$ & $\begin{array}{l}\text { Wilcoxon Sign- } \\
\text { Rank Test } \\
\text { The hypothesis is } \\
\text { accepted }\end{array}$ & $\begin{array}{l}\text { Significantly decreased in the } \\
\text { cyclical consumer sector and } \\
\text { increased in the non-cyclical } \\
\text { consumer sector. }\end{array}$ \\
\hline 8 & $\begin{array}{l}\text { There is a difference in the average net } \\
\text { foreign sell in the announcement that the } \\
\text { new normal will apply to stocks with } \\
\text { different business sectors. }\end{array}$ & $\begin{array}{l}\text { Wilcoxon Sign- } \\
\text { Rank Test } \\
\text { The hypothesis is } \\
\text { accepted }\end{array}$ & $\begin{array}{l}\text { Significantly decreased in the } \\
\text { financials and industrial sectors, } \\
\text { indicating the entry of investment } \\
\text { from outside the country. }\end{array}$ \\
\hline
\end{tabular}

Source: Data Processed by Researchers

\section{DISCUSSION}

Based on data analysis and the results of hypothesis testing, it can be summarized the information obtained from the reactions of Indonesian capital market investors to the announcement of the first Covid-19 patient and the announcement that the new normal will be enacted. The reactions of capital market investors can be found in several industrial sectors that are affected, which are as follows:

1. As a result in testing hypothesis 1 , it was found that there was no significant difference in the average abnormal return on the day of the announcement of the first Covid-19 patient and the announcement 
that the new normal would be enacted. In addition, it was also found that the average significant abnormal return in almost all sectors occurred on the fifth day after the announcement of the first Covid-19 patient. The cyclical consumer sector experienced a negative and most significant abnormal return on the fifth day after the announcement of the first Covid-19 patient. As for the announcement of the implementation of the new normal, namely in the hypothesis test 2 , this sector experienced a significant positive abnormal return on the ninth day before the event. This shows that the cyclical consumer sector was affected the most in the first event, but experienced a good recovery in the second event. This recovery is also seen in the average transaction volume examined in the fourth hypothesis test. The increased average transaction volume in this sector in the second event is an indicator of good stock liquidity. From this information, it can be understood that the cyclical consumer sector experiences high volatility.

2. Based on the results of hypothesis 1 testing, it was also found that the non-cyclical consumer sector experienced a significant abnormal return on the fifth day after the announcement of the first Covid19 patient. The significance of this decrease in average abnormal return is below the cyclical consumer sector. Based on the results of hypothesis 7 testing, this sector also experienced a capital flight due to the announcement of the first Covid-19 patient. However, based on the results of hypothesis 8 testing, this sector is able to experience a recovery in the event of the announcement of the enactment of the new normal as indicated by a significant increase in market capitalization. As for the results of hypothesis 4 testing, which shows that the average trading volume activity of non-cyclical consumer sector stocks, which declines in the event of the announcement of the implementation of the new normal, needs to be investigated further, whether it is caused by low supply or small demand which causes a decrease in trade transactions.

3. This volatility in the cyclical and non-cyclical consumer sectors could be due to the fact that the Indonesian economy is supported by domestic consumption and this sector touches directly on the needs of social lifestyles, which of course are declining due to the Covid-19 pandemic.

4. Based on the results of hypothesis 1 testing, the technology sector is the only sector that is not significantly affected by the announcement of the first Covid-19 patient. Based on the results of hypothesis 6 testing, this sector also looks good in responding to the announcement of the new normal as indicated by a significant increase in market capitalization. This shows that this sector has resilience in stock performance due to Covid-19 pandemic.

5. Based on the results of hypothesis 1 testing, the financial sector experienced a significant negative abnormal return on average due to the announcement of the first Covid-19 patient, but based on the results of hypothesis 3 testing, the shares of this sector remain liquid for trading. Based on the results of hypothesis 8 testing, this sector also responded well to the announcement of the implementation 
of the new normal as indicated by the significant inflow of foreign investment in the sector. This shows that this sector was also affected by the announcement of the first Covid-19 patient, but investors believe that when the new normal is enacted, this sector will be able to recover.

6. Based on the results of hypothesis 1 test, the infrastructures sector experienced a significant average negative abnormal return due to the announcement of the first Covid-19 patient, but based on the results of hypothesis testing 3 , the shares of this sector remained liquid for trading. Meanwhile, based on the results of hypothesis 5 testing, the decline in market capitalization in this sector is the least affected. This shows that this sector has resilience and stability in stock performance.

7. Based on the results of hypothesis 1 testing, the industrials sector experienced a significant negative abnormal return on average due to the announcement of the first Covid-19 patient, but based on the results of hypothesis 6 testing, the shares of this sector were able to respond well to the announcement of the new normal, which is indicated by the increase in market capitalization. Meanwhile, based on the results of hypothesis 8 testing, this sector was able to attract significant foreign capital inflows.

\section{CONCLUSION AND IMPLICATION}

Stakeholders with an interest in the impact of Covid-19 on the economy in Indonesia should pay attention to volatility in the cyclical and non-cyclical consumer sectors. The new normal policy is able to help these two sectors to improve, but these two sectors have a great vulnerability to be affected by developments in the situation. In addition to the new normal policy, incentives on the consumption side, especially for the lower class, are also needed to encourage performance improvements in this sector, namely by increasing the purchasing power of the reduced lower class. Furthermore, it is necessary to further developing business in the technology sector because it is expected to support the Indonesian economy by encouraging market demand and consumption in the technology sector. The technology sector will also support business acceleration in the pandemic era by providing facilities and infrastructure to work and study online. The next research is suggested to add the object of research by using a sample method that can better represent all stock sectors on the Indonesia Stock Exchange. Subsequent research is recommended to take into account the existence of confounding events and confounding effects that are specific to the company or general in nature.

\section{REFERENCES}


Altin, H. 2015. Efficient Market Hypotesis, Abnormal return and Election Periods. European Scientific Journal. 11(34): 169-178.

Ball, R. and P. Brown. (1968). An Empirical Evaluation of Accounting Income Numbers. Journal of Accounting Research. 6:159-178.

Chen, M.-H. Shawn, S. Gon, W. (2007). The impact of the SARS outbreak on Taiwanese hotel stock performance: An event-study approach. Int. J. Hosp. Manag. 26(1), 200-212.

Corrado, C. (1989). A Nonparametric Test for Abnormal Security-Price Performance in Event Studies. Financial Economic. 33:293-311.

Diniar, A.H. and Kiryanto. (2015). Analisis Dampak Pemilu Presiden Jokowi terhadap Return Saham (Studi Kasus Saham LQ-45 di Bursa Efek Indonesia. Jurnal Akuntansi Indonesia. 4(2). 97-108.

Dolley, J.C. (1933). Characteristics and Procedure of Common Stock Split-Ups. Harvard Business Revies. 11:316-326.

Dombrow, J. Rodriguez, M. and Sirmans, C. F. (2000). A Complete Nonparametric Event Approach. Review of Quantitative Finance and Accounting. 14:361-380.

Downes, J. and Goodman, J.D. (2003). Dictionary of Finance and Investment Terms. 6.ed. New York: Barron's.

Fama, E. F., Fisher, L., Jensen, M., and Roll, R. (1969). The Adjustment of Stock Prices to New Information. International Economic Revies. 10:1-21.

Fitriani, F. F. (2020). BOS BI : Capital Outflow Selama Wabah Corona Tembus Rp167,9 Triliun. Retrieved Desember 12, 2020 from https://market.bisnis.com/read/20200401/92/1220841/bos-bi-capitaloutflow-selama-wabah-corona-tembus-rp1679-triliun

Foster, G. (1986). Financials Statement Analysist. Second Edition. Engelwood Cliff, New Jersey: Prentice-Hall International, Inc.

Ghanem, D. and Rosvall, D. (2014). Major World Events Impact on Stock Market Prices-An Event Study. Journal Department of Business Studies Uppsala University. 11(2): 430-445.

Hartono, J. (2003). Teori Portofolio dan Analisis Investasi. $3^{\text {rd }}$ Edition . Yogyakarta: BPFE.

Hartono, J. (2005). Pasar Efisien Secara Keputusan. Jakarta : PT Gramedia Pustaka Utama.

Hartono, J. (2015). Teori Portofolio dan Analisis Investasi. $8^{\text {th }}$ Edition. Yogyakarta : BPFE.

Hartono, J. (2018). Studi Peristiwa : Menguji Reaksi Pasar Modal Akibat Suatu Peristiwa. $1^{\text {st }}$ Edition. Yogyakarta : BPFE.

Hatmanti and Bambang. (2017). Pengaruh Pelantikan Kabinet Kerja Hasil Reshuffle Jilid II Terhadap Harga Saham LQ-45. Jurnal Economia UGM. 13(1): 1-13.

He, P., Sun, Y., Zhang, Y., and Li, T. (2020). Covid-19 Impact on Stock Prices Across Different Sektors An Event Study Based on the Chinese Stock Market. Emerging Markets Finance and Trade. 56 (10) :2198-2212.

Hung, LC. (2013). US Presidential Election and the Taiwanese Stock Market. Journal of International Relations National Chengchi University. 49(1): 71-97.

Insanuddin. (2020). Fakta Lengkap Kasus Pertama Virus Corona di Indonesia. Retrieved June 08, 2020 from https://nasional.kompas.com/read/2020/03/03/06314981/fakta-lengkap-kasus-pertama-viruscorona-di-indonesia

Liu, HY., Manzoor, A., Wang, C., Zhang, L. and Manzoor, Z. (2020). The Covid-19 Outbreak and Affected Countries Stock Markets Response". International Journal of Enviromental Research and Public Health 17, no.8 (April 2020): 2800. 
Mahmood, S., Irfan, M., Iqbal, S., Kamran, M., and ljaz, A. (2014). Impact of Political Events on Stock Market: Evidence from Pakistan. Journal of Asian Business Strategy. 4(12):163-174.

Marinc, R.I.M. Geographic Proximity of Information to Financials Markets and Impact on Stock Prices: Evidence from the Ebola Outbreak. In Proceedings of the 2016 UBT International Conference, Durrës, Albania, 28-30 October 2016.

Murekachiro, D. (2014). Opinion Polls and The Stock Market: Evidence From The 2013 Zimbabwe Presidential Elections. Journal of Finance. 2(4):1-9.

Najaf, K., Najaf, R., Iqbal, A., Shah, I. H. (2015). The Impact of Terrorism And Political Events On Stock Market: Empirical Evidence From Pakistan. International Journal of Scientific Research and Management. 3(6): 3036-3045.

Octafilia, Y. (2016). Dampak Pemilihan Presiden Republik Indonesia Tahun 2014 Terhadap Abnormal return dan Trading volume activity di Bursa Efek Indonesia (Event Study Pada Saham Indeks Kompas 100). E-journal Pelita Indonesia. 1(1): 100-110.

Pransuamitra, P. A. (2020) Pekan Kelam! Market Cap IHSG Menguap 678T Gegara Corona. Retrieved Desember 12, 2020, from https://www.cnbcindonesia.com/market/20200314111931-17144858/pekan-kelam-market-cap-ihsg-menguap-rp-678-t-gegara-corona

Sasongko, J., Widiyanti, M., Taufik. (2015). Reaksi Pasar Modal Atas Peristiwa Pengumuman Presiden RI 2014 (Studi pada Saham Sektor Pertambangan di Bursa Efek Indonesia). Jurnal IImiah Manajemen Bisnis dan Terapan. 12(1): 33-44.

Wong, WY and Hooy, CW. (2016). The Impact of Election on Stock Market Returns of GovernmentOwned Banks: The Case of Indonesia, Malaysia and Thailand. Asian Journal of Business and Accounting. 9(1): 3158.

www.idx.co.id

Yuliana, Y.T. and Sudana. (2015). Reaksi Pasar Saham Terhadap Peristiwa Politik di Parlemen Indonesia Tahun 2014 (Studi Peristiwa Pada Perusahaan Yang Terdaftar Di BEI). Jurnal Manajemen Bisnis Indonesia. 3(1): 14-28.

Yuniarthi and Sujana. (2016). Reaksi Pasar Modal Terhadap Pencalonan Jokowi Menjadi Presiden Republik Indonesia. E-Jurnal Akuntansi Universitas Udayana. 16(2): 951-977. 